V Seminário Anual Científico e Tecnológico | Bio-Manguinhos

\title{
REA 07 - Obtenção da proteína recombinante E2 do vírus Chikungunya como insumo para o desenvolvimento de um novo teste diagnóstico
}

Carolina Lessa-Aquino ${ }^{*}$; Haroldo Cid da Silva Junior ${ }^{1}$; Karen Soares Trinta ${ }^{1}$; Gabriela dos Santos Esteves ${ }^{1}$; Edimilson Domingos da Silva ${ }^{1}$; Marco Alberto Medeiros ${ }^{1}$.

1 Bio-Manguinhos / Fiocruz.

\section{Introdução:}

O vírus Chikungunya (CHIKV) é um membro da família Togaviridae, gênero Alphavirus. Este vírus é transmitido a humanos pela picada de mosquitos do gênero Aedes. O CHIKV tem sido responsável por epidemias em diversos países, inclusive no Brasil, onde emergiu em 2014. O diagnóstico clínico desta arbovirose é dificultado pela sintomatologia inespecífica, sendo a confirmação da doença realizada através de diagnóstico laboratorial por sorologia, qRT-PCR ou isolamento viral. Neste contexto, o desenvolvimento de insumos para o diagnóstico de CHIKV é de extrema relevância para o fortalecimento das políticas públicas de enfrentamento a esta doença.

\section{Objetivo:}

Obter a proteína recombinante E2 de CHIKV (rE2) e avaliar a sua reatividade frente a soros de pacientes com Chikungunya.

\section{Metodologia:}

A sequência correspondente à proteína E2 sem a região transmembrana foi amplificada por PCR e o amplicon foi digerido com as enzimas NdeI e HindIII para clonagem no vetor pET 28a. A clonagem foi confirmada por PCR e sequenciamento nucleotídico. O clone selecionado foi transformado em Escherichia coli BL21 DE(3) Star e a expressão da proteína recombinante foi realizada em meio Terrific Broth, com indução na fase exponencial por IPTG $0,5 \mathrm{mM}$ durante 4 horas a $37^{\circ} \mathrm{C}$. A rE2 foi purificada por IMAC em coluna HP HisTrap, sob condições desnaturantes. A soro-reatividade da proteína foi avaliada para IgG, contra soros positivos para Chikungunya $(n=3)$, Zika $(n=2)$ e Dengue $(\mathrm{n}=2)$, por dot blot e western blot, com detecção por fosfatase alcalina. 


\section{Resultado:}

A sequência foi amplificada por PCR e a clonagem do amplicon no vetor de expressão gerou 8 clones, dos quais 5 foram confirmados quanto à presença do inserto. $\mathrm{O}$ clone 1 apresentou $100 \%$ de identidade e foi selecionado para expressão da rE2. A proteína foi expressa na forma de corpo de inclusão, que foi solubilizado e submetido à purificação. A rE2 foi dialisada em tampão Tris $20 \mathrm{mM}$ L-arginina $75 \mathrm{mM}$ Ureia $2 \mathrm{M}$ e apresentou reatividade IgG positiva apenas para as 3 amostras de soro de indivíduos confirmados para infecção por CHIKV, tanto em dot blot quanto em western blot.

\section{Conclusão:}

A proteína $\mathrm{rE} 2$ de $\mathrm{CHIKV}$ produzida apresentou soro-reatividade específica para pacientes com Chikungunya. Novos ensaios serão realizados a fim de avaliar a sua reatividade frente a um painel sorológico mais abrangente e confirmar o seu potencial diagnóstico.

\section{Palavras-chave: Febre Chikungunya; Proteína Recombinante; Diagnóstico}

